DOI:

UDC 536.425:538.91

B. Sereda ${ }^{1}$, Ph.D., Professor, seredabp@ukr.net

B. Hina ${ }^{2}$, Doctor of Physical and Mathematical Sciences, Professor, Chief Researcher

I. Kruglyak ${ }^{1}$, Ph.D., Associate Professor

D. Sereda ${ }^{1}$, Ph.D., Senior lecturer

${ }^{1}$ Dniprovsky State Technical University, Kamianske

${ }^{2}$ Physics and Technology Institute of the National Academy of Sciences of Belarus, Minsk

\title{
MATHEMATICAL MODELING OF DIFFUSION LAYERS FORMATION USING COMPOSITIONAL SATURATING BATCHES CHARGES
}

The problem of chemical-thermal treatment of steel using composite saturating charge ECD (Energy component of diffusion). In the system under consideration, a complex of processes occurs: wave propagation in the charge layer on the steel surface, non-stationary heat removal into the interior of the sample, and non-stationary diffusion of atoms of the saturating element deep into the steel under non-isothermal conditions. In this case, that part of the surface from which the diffusion saturation of steel occurs expands as the wave moves. In this work, the thermal conductivity $\lambda$ is not an additive, but a structure-dependent quantity. However, for simplicity, in the area where ECD occurs, the additive formula is usually adopted: $\lambda=\lambda_{c h}(1-\eta)+\lambda_{p r} \eta$, and for steel $\lambda=\lambda_{\text {st. }}$ For the $i$-th individual substance, a linear dependence of thermal conductivity on temperature was used: $\lambda_{i}(T)=\lambda_{0}+\lambda_{T} T$. After the ECD wave has reached the edge, i.e. the charge has fully reacted, the diffusion of atoms from the surface and conductive heat transfer in the steel continue during the holding time $t_{h}$. This problem is two-dimensional, nonstationary, and essentially nonisothermal.

Keywords: composite saturating charge; border conditions; energy component of diffusion; conductive heat transfer; nonlinear unsteady equation.

Розглянуто задачу про хіміко-термічній обробиі сталі з використанням композіиійного насічувального середовища з Використання ECD (Energy component of diffusion). У даній системі відбувається комплекс прочесів: поширення хвилі в шарі шихти на поверхні стали, нестаиіонарний тепловідвід вглиб зразка і нестаціонарна дифузія атомів насичує елемента вглиб стали в неізотермічних умовах. При иьому та частина поверхні, з якої йде дифузійне насичення стали, розширюється в міру руху хвилі. В роботі теплопровідність $\lambda \epsilon$ не адитивної, а структурно-залежної величиною. Однак для простоти в області, де протікає ECD, зазвичай приймають аддитивную формулу: $\lambda=\lambda_{c h}(1-\eta)+\lambda_{p r} \eta$, а для сталі $\lambda=\lambda_{\text {st. }}$ Для $i$-го індивідуального речовини використовували лінійну залежність теплопровідності від температури: $\lambda_{i}(T)=\lambda_{0}+$ $\lambda_{T} T$. Після того, як хвиля ЕСD добігла до краю, тобто шихта повністю прореагувала, дифузія атомів з поверхні і кондуктивний теплоперенос в стали тривають протягом часу витримки $t_{h}$. Таке завдання є двовимірної, нестачіонарної і істотно неізотермічної.

Ключові слова: композииійне насичуюче середовище; граничні умови; енергетична складова дифузї; провідний теплообмін; нелінійне нестаціонарне рівняння.

\section{Problem's Formulation}

Obtaining diffusion protective layers with the use of composite saturating media - a new type of CHT which uses saturating elements, which in one technological cycle provide the required type of alloying with a minimum time of their formation. Diffusion protective layers obtained using composite saturating charge (CSC) are an effective method of increasing the reliability of machine parts and process equipment by creating on the surface of the machined parts layers doped with aluminum, vanadium, titanium, molybdenum, boron, tungsten, which have a unique set of physical and chemical properties.

Let us consider the problem of chemical-thermal treatment (CHT) of steel using a composite saturated charge using ECD (Energy component of diffusion). The situation under consideration is 
shown schematically in Fig. 1. A layer of reactive charge ABCD with a thickness of $h_{c h}=A D$ is located on the surface of a steel sample $C D E F$ with a thickness of $h_{s t}=D E$; the length of the sample with a layer of charge $L=A B=D C$. The $0 x$ xis is directed from left to right - along the motion of the ECD wave, and the $0 y$ - axis - into the depth of the steel. The front of the ECD wave is shown to be curved, since heat removal into steel will inevitably slow down its movement from the side adjacent to the $D C$ surface.

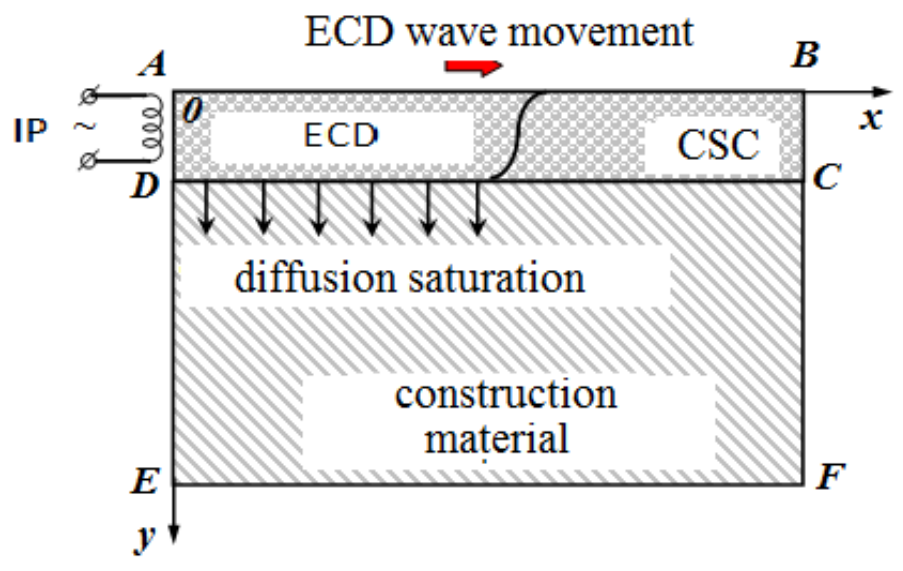

Fig. 1. Scheme of the saturation process in a composite saturated medium

At the initial moment of time $t=0$ the sample and the charge are at a constant temperature $T_{0}$; this temperature is higher than room temperature, but lower than that at which an exothermic reaction can begin in the ECD charge. On the left edge of $A D$, i.e. at $x=0, y=[0, D]$ at the initial moment of time $t=0$ the ECD charge is ignited due to external heating by an incandescent coil with a constant temperature $T_{i g}$ for a time $t_{i g}$ - until a combustion wave is formed, propagating through the layer charge along the $0 x$ axis. Further, in section $A D$ external heating stops. For simplicity, it is assumed that the sample surfaces $A B, B F, E D$ and $E F$ are thermally insulated, i.e. there is no heat exchange with the environment; The same applies to the surface $A D$ after the end of the ignition, i.e. for $t>t_{i g}$. During an exothermic reaction, active atoms of a saturating element are formed in the charge layer, which diffuse deep into the steel from the $D C$, boundary, while ahead of the combustion wave front, i.e. where the reaction has not yet taken place and active atoms have not been formed, diffusion saturation does not occur. The heat from the afterburning zone of the ECD wave is partially removed deep into the steel sample.Thus, a complex of processes occurs in the system under consideration: propagation of the ECD wave in the charge layer on the steel surface, unsteady heat removal into the interior of the sample, and unsteady diffusion of atoms of the saturating element deep into the steel under non-isothermal conditions. In this case, that part of the DC surface from which the steel diffusion saturation expands as the ECD wave moves. After the ECD wave has reached the $\mathrm{BC}$ edge, i.e. the charge is completely burnt, the diffusion of atoms from the DC surface and conductive heat transfer in the steel continue during the holding time $t_{h}$. This problem is two-dimensional, nonstationary, and essentially nonisothermal.

\section{Presenting main material}

For the mathematical formulation of the above physical problem, it is necessary to make a number of assumptions that do not reduce the level of generality of the problem and do not distort the physics of the process:

- on the DC surface (boundary steel / ECD charge and steel / ECD product) there is an ideal thermal contact, i.e. there are no discontinuities (pores, cracks) or intermediate layers of substances with low thermal conductivity (for example, scale);

- the concentration of the saturating element along that part of the DC surface where the exothermic reaction has occurred is the same and does not change over time; it is equal to zero where the 
reaction has not yet occurred, i.e. ahead of the ECD wave front; after the completion of the reaction over the entire DC surface, this concentration is also taken constant during the entire holding time $t_{h}$;

- at the $D C$ boundary, we take an ideal diffusion contact, i.e. there are no intermediate layers or impurities that could slow down the transition of active atoms formed during ECD to the surface layer of steel.

The kinetics of the interaction of reagents in the ECD wave is very complex and insufficiently studied $[1,2]$. The same applies to the kinetics of generation of active atoms in the ECD wave, which will diffuse into steel. In this regard, we will describe the kinetics of interaction and heat release in the ECD wave using the relatively simple Khaikin-Merzhanov model [3 - 7], and consider the first-order reaction.

The propagation of the ECD wave in the charge layer $A B C D$ and the conductive heat transfer in the steel sample $C D E F$ can be described by the same two-dimensional non-stationary nonlinear equation of heat conductivity with coefficients depending on the coordinates $\mathrm{x}, \mathrm{y}$ and on the temperature $\mathrm{T}$; in this case, the term describing the rate of heat release in the $C D E F$ region will be equal to zero:

$$
\begin{gathered}
\rho c \frac{\partial T}{\partial t}=\frac{\partial}{\partial x}\left(\lambda \frac{\partial T}{\partial x}\right)+\frac{\partial}{\partial y}\left(\lambda \frac{\partial T}{\partial y}\right)+F, \quad F=\rho_{p r} Q \frac{\partial \eta}{\partial t}, \\
\frac{d \eta}{d t}=(1-\eta)^{n} k_{0} \exp \left(-\frac{E_{r}}{R T}\right) .
\end{gathered}
$$

Here $T-$ is the temperature $[\mathrm{K}], c=c(x, y, T)-$ is the mass heat capacity $[\mathrm{J} /(\mathrm{kg} \cdot \mathrm{K})]$, $\rho=\rho(x, y, T)$ - is the density $\left[\mathrm{kg} / \mathrm{m}^{3}\right], \lambda=\lambda(x, y, T)$ - is the thermal conductivity coefficient $[\mathrm{W} /(\mathrm{m} \cdot \mathrm{K})], \eta-$ is the degree of conversion in the ECD reaction (dimensionless quantity), $\leq \eta \leq 1, n$ - is the order of the reaction (as noted above, $n=1$ ), $Q$ - is the heat release of the reaction per unit mass of the product $[\mathrm{J} / \mathrm{kg}], k_{0}$ - is the pre-exponent in the Arrhenius expression for the reaction rate $\left[\mathrm{c}^{-1}\right], E_{r}$ - is the activation energy of the gross reaction in the ECD wave $[\mathrm{J} / \mathrm{mol}], R-$ is the universal gas constant, $R=8,314 \mathrm{~J} /(\mathrm{mol} \cdot \mathrm{K})$, the subscript " $p r$ " means the reaction product.

Formula (1) is a nonlinear non-stationary heat conduction equation, in which the last term on the right-hand side (value F) has the meaning of a heat source (rate of heat release) due to the occurrence of a heterogeneous exothermic reaction. The ordinary differential equation (2) describes the reaction rate according to the Khaikin-Merzhanov macrokinetic model.

Let us describe the parameters included in the heat conduction equation with a source (1). The amount of heat release $Q=-\Delta H_{r}$, where $\Delta H_{r}$ - is the enthalpy change for an exothermic reaction $\left(\triangle H_{r}<0\right)$, it can be determined on the basis of thermodynamic reference books, for example [8-12]. In the area $A B C D$, i.e. for $0<x \leq D, 0<y \leq B$, the heat source $\mathrm{F}$ is nonzero and the degree of conversion $\eta$ is determined from the solution of equation (2). In the $C D E F$ (for $D<x \leq E, 0<y \leq B$ ) in equation (1) $F=0, \eta=0$, i.e. it is solved without a heat source and is an ordinary two-dimensional nonlinear equation of heat conduction, and equation (2) vanishes identically, i.e. it is not calculated. follows:

Heat capacity $c$ and density $\rho$ are additive quantities, therefore, in equation (1) is determined as

- in the domain $A B C D: c=c_{c h}(1-\eta)+c_{p r} \eta, \quad \rho=\rho_{c h}(1-\eta)+\rho_{p r} \eta$

- in the $C D E F: c=c_{s t}, \rho=\rho_{s t}$,

where the subscripts $c h, p r$ and $s t$ stand for charge, product of CBC (product) and steel (steel). For each individual substance $\mathrm{i}$ (charge component, reaction product, steel or pure iron), the temperature dependence of the heat capacity is usually written in the form $c_{i}(T)=A+B T+C T^{-2}+D T^{2}$ where the values of the coefficients $\mathrm{A}, \mathrm{B}, \mathrm{C}$ and $\mathrm{D}$ are available in thermodynamic reference books [8-12].

Thermal conductivity $\lambda$ is not an additive, but a structure-dependent quantity. However, for simplicity, in the ABCD region, where ECD occurs, the additive formula is usually adopted: $\lambda=\lambda_{c h}(1-\eta)+\lambda_{p r} \eta$, and for steel (region $\left.C D E F\right) \lambda=\lambda_{s t}$. For the i-th individual substance, a linear dependence of thermal conductivity on temperature is often used: $\lambda_{i}(T)=\lambda_{0}+\lambda_{T} T$.

The initial conditions for the heat conduction equation with a source (1) and kinetic equation (2) have the form 


$$
T(x, y, t=0)=T_{0}=\text { const }, \quad \eta(x, y, t=0)=0 .
$$

Since the initial temperature $T_{0}$ is chosen so that at it the reaction rate is negligible, then when numerically solving Eq. (2), one can use the "trimming" of the Arrhenius exponent: at $T$ при $T \leq T_{0}$ $d \eta / d t=0$.

Let us write the boundary conditions to the heat conduction equation (1). During firing $t \leq t_{i g}$ at the edge $x=0,0<y \leq D$ condition of the first kind is set:

$$
\mathrm{T}\left(x=0,0<y \leq D, t \leq t_{i g}\right)=T_{i g} .
$$

On all other edges of the sample during the entire process time $(t>0)$, as well as on the edge $A D(x=0,0<y \leq D)$ after ignition $\left(t>t_{i g}\right)$ a boundary condition of the second kind is set (absence of heat exchange with environment):

$$
\begin{aligned}
& -\left.\lambda \frac{\partial T}{\partial x}\right|_{x=0}=-\left.\lambda \frac{\partial T}{\partial x}\right|_{x=B}=0 \\
& -\left.\lambda \frac{\partial T}{\partial y}\right|_{y=0}=-\left.\lambda \frac{\partial T}{\partial y}\right|_{y=E}=0 .
\end{aligned}
$$

Thus, the thermal problem for the considered situation is formulated.

The diffusion equation in steel in the $C D E F$ region (see Fig. 1) is written as Fick's II law, taking into account the Arrhenius dependence of the diffusion coefficient $\mathrm{D}$ of the saturating element at each point on temperature:

$$
\begin{gathered}
\frac{\partial C}{\partial t}=\frac{\partial}{\partial x}\left(D \frac{\partial C}{\partial x}\right)+\frac{\partial}{\partial y}\left(D \frac{\partial C}{\partial y}\right), \\
D=D_{0} \exp \left(-\frac{E_{D}}{R T}\right) .
\end{gathered}
$$

Here $C-$ is the concentration of the diffusing element, $E_{D}-$ is the activation energy of its diffusion in steel (or pure iron), $D_{0}$ - is the pre-exponential factor; the values of $E_{D}$ and $D_{0}$ for the diffusion of many elements in $\alpha$ - and $\gamma$-Fe are given in the reference literature, for example [13].

The initial condition to eq. (7) has a simple form

$$
C(x, y, t=0)=0 \text {. }
$$

The boundary conditions for the diffusion equation (7) are as follows. Since there is no mass transfer of the steel sample with the environment, at the boundaries $D E, C F$ and $E F$ (see Fig. 1), we write down conditions of the second kind, which are similar to expressions (5) and (6):

$$
\begin{gathered}
-\left.D \frac{\partial C}{\partial x}\right|_{x=0, y \in D E}=-\left.D \frac{\partial C}{\partial x}\right|_{x=B, y \in D E}=0, \\
-\left.D \frac{\partial C}{\partial y}\right|_{y=E, x \in A B}=0 .
\end{gathered}
$$

On the $C D$ border, the situation is different. The ECD wave moves along it in the reaction mixture in the direction of the $0 \mathrm{x}$ axis, and active atoms of the saturating element are generated in the region behind its front (in the zone of thermal reaction and the zone of afterburning of the ECD wave). Since we consider the ideal diffusion contact of the steel sample with the region $A B C D$, the boundary conditions of the first kind should be set at the $D C$ boundary: $C(y=D, x<P)=C_{s}$ and $C(y=D$, $x \geq P)=0$, where $C_{s}$ - is the concentration of the saturating element formed as a result of ECD, $P(t)$ - is the current coordinate of the combustion front on the surface $D C$, which can be defined as a point where $\eta=0,5[[7]]$.

But here the following circumstance arises: when the front is displaced to the next point along the $0 \mathrm{x}$ axis, the boundary condition in it will change abruptly, which can lead to the cycling of the computer program in the numerical solution of the above problem. In addition, in the ECD wave, in front of the narrow zone of rapid reaction, there is a wide Michelson zone, in which the charge is heated by the heat flow from the reaction zone. For the considered two-dimensional problem, the heat 
from the specified zone will be partially removed to the surface region of the steel located in front of the ECD wave front, and then the diffusion coefficient $\mathrm{D}$ there will increase. Then, at a low velocity of propagation of the ECD wave, a situation is theoretically possible when the atoms of the saturating element diffuse forward along the $0 x$ axis from the surface zone of the steel located behind the ECD front. This, again, will lead to significant difficulties in the numerical solution of the problem. Therefore, it is better to set boundary conditions of the third kind, which in the situation under consideration we will write in an unusual form, taking into account the motion of the combustion front along the DC line:

$$
-\left.D \frac{\partial C}{\partial y}\right|_{x, y=D}=\left.K_{C} \eta\right|_{x, y=E}\left(C_{s}-\left.C\right|_{x, y=D}\right),
$$

where $\left.\eta\right|_{x, y=E}$ and $\left.C\right|_{x, y=D}$ - respectively, the degree of conversion and concentration of the diffuser in steel at a point with the current coordinate $x$ at the boundary $D C$ (i.e., at $y=D$ ), and the parameter $K_{C}$ is the coefficient of mass transfer between the steel surface and the reacted charge. At a high value of $K_{C}$ the concentration of diffusant in the steel at a given point $C \rightarrow C_{s}$, and then the condition of the III kind (11) will be reduced to the condition of the I type (constant concentration at a given point).

Thus, the diffusion part of the problem is formulated completely. The heat conduction equations with a source (1), (2) and initial (3) and boundary conditions (4) - (6) must be solved together with the diffusion equation (7) with the initial condition (9), boundary conditions (10)-(13) and expression for the diffusion coefficient (8).

Equations in dimensionless form: instead of an infinite region, we will consider a finite one with the size $X_{\max }$. To develop a method for the numerical solution of the Stefan problem, it is necessary to bring all equations to a dimensionless form:

$$
\begin{aligned}
& x=X / X_{0}, x_{\max }=X_{\max } / X_{0}, \tau=t / t_{0}, \theta=\left(T-T_{0}\right) / \Delta T, \Delta T=T_{\max }-T_{0}, \\
& \bar{\rho}=\rho_{k} / \rho_{0}, \bar{c}_{p, k}=c_{p . k} / c_{0}, \bar{\lambda}_{p, k}=\lambda_{p . k} / \lambda_{0}, k \equiv l, s,
\end{aligned}
$$

where $t_{0}$ and $X_{0}$ - are the characteristic scales in time and distance, $\rho_{0}, c_{0}$ and $\lambda_{0}$ - are the characteristic values of density, heat capacity and thermal conductivity, respectively, $x$ and $\tau$ - are the dimensionless spatial coordinate and time, respectively, $\theta-$ is the dimensionless temperature, $T_{\max }-$ is the maximum the possible temperature of the melt in the process under consideration, $\bar{\rho}, \bar{c}$ and $\bar{\lambda}-$ dimensionless (scaled) density, heat capacity and thermal conductivity, respectively.

\section{Conclusions}

Thus, the diffusion part of the problem is formulated completely. The heat conduction equations with a source (1), (2) and initial (3) and boundary conditions (4) - (6) must be solved together with the diffusion equation (7) with the initial condition (9), boundary conditions (10)-(13) and expression for the diffusion coefficient (8).

In the future, it is necessary to build a finite-difference scheme, calculate the running coefficients and numerically solve the finite-difference equations by the iteration method.

\section{References}

[1] A.S. Rogachev, A.S. Mukasyan. Combustion for the synthesis of materials: an introduction to structural macrokinetics. - Moscow: Fizmatlit, 2012 .- 400 p.

[2] B.B. China Combustion Synthesis of Advanced Materials. - New York, NY: Nova Science Publ., Inc., 2010. - 110 pp.

[3] K.G.Shkadinsky, B.I.Khaikin, A.G. Merzhanov. Propagation of a pulsating front of an exothermic reaction in a condensed phase // Physics of combustion and explosion, 1971, v. 7, no. 1, pp. $19-28$.

[4] A.P. Aldushin, B.E. Khaikin. On the theory of combustion of mixed systems forming condensed reaction products // Physics of Combustion and Explosion, 1974, No. 3, pp. 313-323. 
[5] T.P. Ivleva, A.G. Merzhanov, K.G.Shkadinsky // On the regularities of the spin mode of propagation of the combustion front // Physics of combustion and explosion, 1980, v.16, No. 2, p. 310.

[6] A.N. Firsov, K.G. Shkadinsky. On combustion of gas-free compositions in the presence of heat loss // Physics of combustion and explosion, 1987, v.23, No. 3, pp. 46-52.

[7] B. M. Khusid, B. B. Khina, E. A. Bashtovaya. Numerical study of thermal processes during quenching of matter in an ECD wave // Physics of Combustion and Explosion, 1991, v.27, no. 6, pp.64-72.

[8] O. Kubashevsky, S.B. Olkokk. Metallurgical thermochemistry. - M .: Metallurgy, 1982 .-- 392 p.

[9] I.Barin, O.Knacke. Thermochemical Properties of Inorganic Substances. - Berlin: SpringerVerlag, 1973. - 949 pp.

[10] I.Barin. Thermochemical Data of Pure Substances. 3rd Edition. - New York, NY: VCH Publishers, Inc., 1995. - 2003 pp.

[11] M. W. Chase, jr. NIST-JANAF Themochemical Tables, 4th edition // Journal of Physics and Chemistry Reference Data. Monograph 9, 1998, p. 1-1951.

[12] M. Binnewies, E. Milke. Thermochemical Data of Elements and Compounds. 2nd edition. Weinheim: Wiley-VCH Verlag GmbH, 2002. - 928 pp.

[13] Smithells Metals Reference Book. 8th edition. Ed. by W.F. Gale and T.C. Tomeier. - Amsterdam: Elsevier Inc., 2004.2072 pp.

\section{МАТЕМАТИЧНЕ МОДЕЛЮВАННЯ ФОРМУВАННЯ ДИФУЗІЙНИХ ШАРІВ З ВИКОРИСТАННЯМ КОМПОЗИЦИЙНОГО НАСИЧУВАЛЬНОГО СЕРЕДОВИЩА \\ Середа Б.П., Хина Б.Б.,. Кругляк І.В, Середа Д.Б.}

\section{Реферат}

Розглянуто задачу про хіміко-термічній обробці сталі з використанням композіційного насічувального середовища з Використання ECD (Energy component of diffusion). У даній системі відбувається комплекс процесів: поширення хвилі в шарі шихти на поверхні стали, нестаціонарний тепловідвід вглиб зразка і нестаціонарна дифузія атомів насичує елемента вглиб стали в неізотермічних умовах. При цьому та частина поверхні, з якої йде дифузійне насичення стали, розширюється в міру руху хвилі. В роботі теплопровідність $\lambda \epsilon$ не адитивної, а структурно-залежної величиною. Однак для простоти в області, де протікає $\mathrm{ECD}$, зазвичай приймають аддитивную формулу: $\lambda=\lambda_{c h}(1-\eta)+\lambda_{p r} \eta$, а для сталі $\lambda=\lambda_{s t}$. Для $i$-го індивідуального речовини використовували лінійну залежність теплопровідності від температури: $\lambda_{i}(T)=\lambda_{0}+\lambda_{T} T$. Після того, як хвиля ECD добігла до краю, тобто шихта повністю прореагувала, дифузія атомів 3 поверхні і кондуктивний теплоперенос в стали тривають протягом часу витримки $t_{h}$. Таке завдання є двовимірної, нестаціонарної і істотно неізотермічної.

Кінетика взаємодії реагентів в хвилі ECD носить досить складний характер і $є$ недостатньо вивченою. Те саме можна сказати і до кінетики генерації активних атомів в хвилі ECD, які будуть дифундувати в сталь. У зв'язку з цим будемо описувати кінетику взаємодії і тепловиділення в хвилі ECD з використанням відносно простий моделі Хайкіна-Мержанова, і розглядати реакцію I-го порядку. Поширення хвилі ECD в шарі KHC і кондуктивне тепло перенос в сталевому зразку можна описати одним і тим же двовимірним нестаціонарним нелінійним рівнянням теплопровідності з коефіцієнтами, залежними від координат $x, y$ і від температури $T$; при цьому член, що описує швидкість тепловиділення, в області буде дорівнювати нулю. 


\section{Література}

[1] А.С.Рогачев, А.С.Мукасьян. Горение для синтеза материалов: введение в структурную макрокинетику. - М.: Физматлит, 2012. - 400 с.

[2] B.B.Khina Combustion Synthesis of Advanced Materials. - New York, NY: Nova Science Publ., Inc., 2010. - 110 pp.

[3] К.Г.Шкадинский, Б.И.Хайкин, А.Г.Мержанов. Распространение пульсирующего фронта экзотермической реакции в конденсированной фазе // Физика горения и взрыва, 1971, т.7, № 1, c.19-28.

[4] А.П.Алдушин, Б.Е.Хайкин. К теории горения смесевых систем, образующих конденсированные продукты реакции // Физика горения и взрыва, 1974, № 3, с.313-323.

[5] Т.П.Ивлева, А.Г.Мержанов, К.Г.Шкадинский // О закономерностях спинового режима распространения фронта горения // Физика горения и взрыва, 1980, т.16, № 2, с.3-10.

[6] А.Н.Фирсов, К.Г.Шкадинский. О горении безгазовых составов при наличии теплопотерь // Физика горения и взрыва, 1987, т.23, № 3, с.46-52.

[7] Б.М.Хусид, Б.Б.Хина, Е.А.Баштовая. Численное исследование тепловых процессов при закалке вещества в волне СВС // Физика горения и взрыва, 1991, т.27, № 6, с.64-72.

[8] О.Кубашевский, С.Б.Олкокк. Металлургическая термохимия. - М.: Металлургия, 1982. 392 c.

[9] I.Barin, O.Knacke. Thermochemical Properties of Inorganic Substances. - Berlin: SpringerVerlag, 1973. - 949 pp.

[10] I.Barin. Thermochemical Data of Pure Substances. 3rd Edition. - New York, NY: VCH Publishers, Inc., 1995. - 2003 pp.

[11] M.W.Chase, jr. NIST-JANAF Themochemical Tables, 4th edition // Journal of Physics and Chemistry Reference Data. Monograph 9, 1998, p.1-1951.

[12] M.Binnewies, E.Milke. Thermochemical Data of Elements and Compounds. 2nd edition. Weinheim: Wiley-VCH Verlag GmbH, 2002. - 928 pp.

[13] Smithells Metals Reference Book. 8th edition. Ed. by W.F.Gale and T.C.Totemeier. - Amsterdam: Elsevier Inc., 2004. 2072 pp. 